\title{
$\mathrm{RC}$ 造建築物における屋上植栽の \\ 室内熱環境の調整効果に関する研究
}

\author{
堀口 剛*1 梅干野昆*2 白井一義*3
}

\section{A Study on Thermal Control Effects for Room by Rooftop Planting on RC Building}

\author{
Horiguchi, Takeshi, Hoyano, Akira and SHIRAI, Kazuyoshi
}

\section{要旨}

屋上植栽による室内への熱環境調整効果は, 植栽を含めた屋根の断面構造に加えて, 建 築の構造, 居住者の生活様式, その地域の気象条件などによっても大きく異なると考えら れる。そこで, 本報では以下の 2 つの方法により, RC 造建築に施された屋上植栽の室内に 及ぼす熱環境調整効果を考察した。

はじめに, 屋上植栽の施された $\mathrm{RC}$ 造建築について, 実際に居住者が生活している部屋を 対象として, 屋根の断面温度・熱流分布を中心に夏から冬にかけて実測調査し, 屋上植栽 の室内への熱環境調整効果を明らかにした。

つぎに, 実測結果をもとに数值計算に必要な葉群層の熱的特性を明らかにするとともに, 屋上断面構造として植栽の有無, 盛土層の厚さ, 土壌の含水状態, 断熱材の有無等の種々 の条件を設定して，室内気温を夏季と冬季で一定とした場合の各々 1 ケ月間と，居住者に よって室温が変化する場合の夏季の 1 日について数值計算を行った。その結果得られた天 井表面温度と室内気温との差を指標にして, 屋上植栽の室内熱環境調整効果について考察 した。

\section{1. はじめに}

屋上植栽の熱的特性については, 既に多くの研究 がなされてきている。芝生試験体を製作し, その照 り返し防止・焼け込み防止効果の検討を行ったも $の^{1)}$, 芝生と芝生以外の土・コンクリート等との比較 と, 熱特性としての芝生の蒸発散作用に言及したも

キーワード：屋上植栽, 盛土層, 断面温度分布, 熱物性値, 屋上構造, 数值計算

Key words : Rooftop planting, Soil-Layer, Sectional Temperature Distribution, Termal Property, Structure of Roof, Numerical Simulation

*1 東京工業大学大学院総合理工学研究科 日本セメント(獭)

$* 2$ 東京工業大学大学院総合理工学研究科

*3 東京工業大学大学院総合理工学研究科
の ${ }^{2)}$,さらにそれに加えて地盤内の伝熱シミュレー ションを検討したもの光, 屋上植栽をパッシブ手法 としてとらえ, その省エネルギー効果を考察したも の ${ }^{4)}$ な゙がある。また, 芝生以外の植栽地と机による 日陰舗装地及び日向舗装地の比較による夏の日の蒸 発散効果と日射遮蔽効果を述べたもの ${ }^{5)}$, 人工軽量 培地での草本, 地被類の屋上から室内への熱流及び 1 日当たりの蒸散による潜熱を求めたもの息があ る。筆者らもすでに熱収支計算のために必要となる 芝生葉群層の熱物性值に関する知見を得て ${ }^{7), 8)}$ きた が，屋上植栽の室内熱環境調整効果を検討するため には, さらに, 建築の構造, 植栽基盤の構造, 居住 者の生活様式，気象条件や季節変化等も同時に考慮 して検討することが必要であると考える。 そこで本報では, 屋上植栽構造としてサツキが植 
栽された厚い盛土層を持つ $\mathrm{RC}$ 造建築を対象とし て，居住者が実際に日常生活をしている状態を夏か ら冬にかけて実測し, 冷暖房・照明等の居住者の生 活による日々の変化や, 季節による外気象の変化な どをふまえた上での, 屋上植栽による室内熱環境調 整効果を把握する。次に, 外気象と室内気温を入力 条件として下記の数值計算を行うために, 屋上植栽 の伝熱モデル化を行い, 必要なパラメータについて その值を実測結果から求める。さらに, 屋上断面構 造について(1)植栽の有無, (2)盛土層の厚さ, (3)土壌 の含水状態, (4)断熱材の有無等の異なる場合を設定 し, 差分法を用いて数值計算を実行する。その結果 求められた天井表面温度と室温の差を指標として, 屋上植栽の室内熱環境調整効果を検討する。

\section{2. 実測調査による夏から冬にかけての室内熱環 境調整効果の検討}

本章では屋上植栽としてサツキ植栽が施された $\mathrm{RC}$ 造建物を対象として, 屋上断面温度と熱流, 盛土 層の含水率, 室内気温, 外気象条件等を, 居住者が 日常生活をしている状態で夏から冬にかけて実測す ることにより, 季節や居住者のライフスタイルを考 慮した屋上植栽の室内熱環境の調整効果を考察す る。

\section{1 実測対象の概要}

実測の対象としたのは, 大阪の市街地の中に建設 された実験集合住宅（写真 1 , 図 1) である。建物 の概要は地上 6 階地下 1 階で, B 1〜2 階までが鉄 筋コンクリート造であり, $3 \sim 6$ 階がプレキャスト

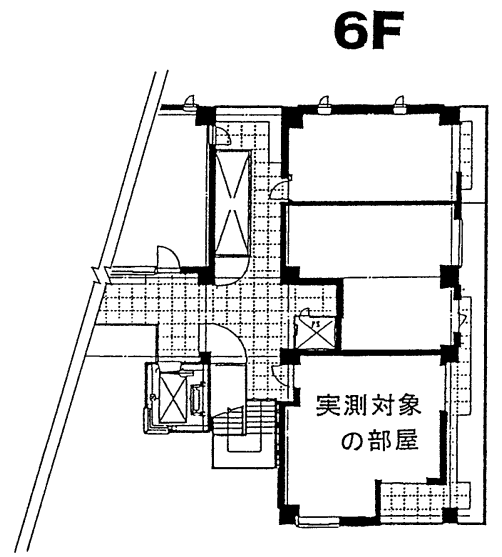

コンクリート十鉄筋コンクリート造である。環境に 対する配慮として中庭にはミニサンクチュアリ, ベ ランダ，屋上には植栽が施されており，低木，中木 が植えられている。図10平面図に示すように，今 回の測定対象は最上階東側住戸とその屋上である。

対象とした屋上植栽は常緑低木のサツキツツジで 高さは30〜 $40 \mathrm{~cm}$, 植栽密度は 9 株 $/ \mathrm{m}^{2}$ であり通常 の植え込みの状態といえる。

盛土層にはパーライトを主原料とした超軽量の人 工土壌を使用しており, 盛土厚さは $450 \mathrm{~mm}$ である。 盛土層上部には合成樹脂系の保水材が $20 \mathrm{~mm}$ 埋め 込まれ, 盛土層下部には排水層として $150 \mathrm{~mm}$ パー ライトが敷き込まれている。散水は，3 回/日（1時, 9 時, 17時)で, 1 回 $1 \mathrm{~m}^{2}$ 当たり夏期 ( 8 月 13 日〜 9 月25日）には $1.8 l$ ，それ以外の季節（ 9 月26日〜 1

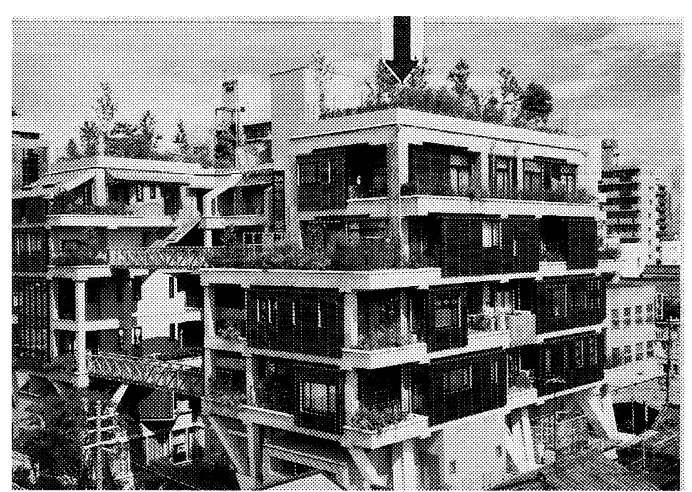

写真 1 実験集合住宅

Photo 1 Residential apartment building used for experiment

\section{RF}

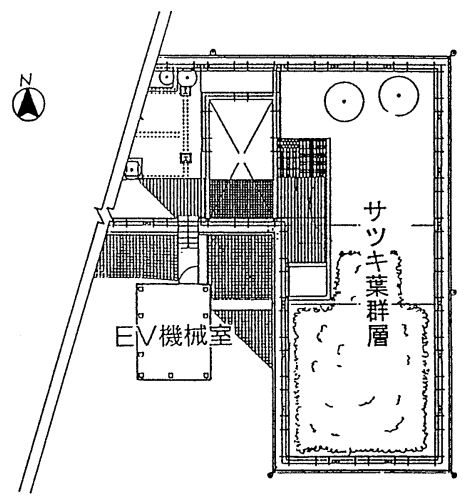

図 1 屋上平面図

Fig. 1 Drawing of rooftop 
月10日）は1.3lの給水を行った。

対象室内の居住者は，夫婦 2 人家族で月〜金曜日 は昼間は不在の時が多い。天井には埋め込み式の照 明灯 $\left(60 \mathrm{~W} \times 9\right.$ 個所 $\left./ 26 \mathrm{~m}^{2}\right)$ が埋設され, 夜間帰宅 時から就寝時まで点灯する。夏季在宅時の冷房設定 温度は $26^{\circ} \mathrm{C}$, 不在時は自動空調, 冬季は暖房を作動 し不在時は停止していた。

\section{2 測定項目及び方法}

断面温度の測定については, $0.3 \mathrm{~mm} \phi$ の 型熱 電対を使用し, 熱流は80 $\mathrm{mm} \times 20 \mathrm{~mm} \times$ 厚さ $2 \mathrm{~mm}$ の熱流計を用いた。サツキ葉群層表面温度は, 葉群 層の上方 $1.5 \mathrm{~m}$ に放射温度計を設置し測定した。土 壌含水量の測定には $\mathrm{pF}$ 值を測定する土壌水分計を 用い, 土壌深さ $70 \mathrm{~mm}$ と $370 \mathrm{~mm}$ に設置した。

外気象としては, 気温と湿度を屋上植栽付近に設 置した百葉箱内の温湿度計で測定し，水平面全天日

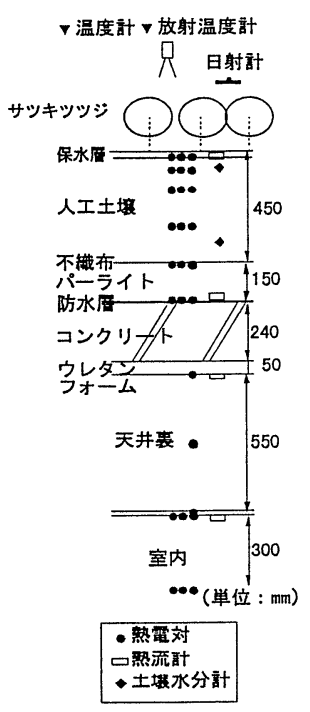

図 2 屋上植栽断面図

Fig. 2 Cross ${ }^{-}$sectional drawing of roof-top planting
射量は屋上に取り付けた日射計で測定した。

実測期間は，夏から冬の期間，すなわち1995年 8 月13日から1996年 1 月 10 日迄行った。測定間隔は 10 分, データロガーを用いて自動計測し, パーソナル コンピューターに収録した。図 2 の屋上植栽断面図 に各測定項目の測定機器設置位置を示す。

\section{3 盛土層の含水率の長期変化}

土壌深70 $\mathrm{mm}$ と $370 \mathrm{~mm}$ における $\mathrm{pF}$ 值の 8 月か ら 1 月の変化を図 3 に示す。保水材が土壌上部に使 用されていることと，1日 3 回定期的に散水してい ることによりその值は殆ど変化がなく, 土壌の各部 位の含水率は実測期間中はほぼ一定で, 湿った状態 であった。なお, $\mathrm{pF}$ 值は盛土層の上部の方が下部よ り常に高かった。

\section{4 断面温度分布の日変化特性}

晴天日が数日続いた，夏と冬の典型的な晴天日の 断面温度分布の変化を図 4 に示す。

図 4 から夏季における昼間の葉群層上表面温度 は, 日射を受けているにもかかわらず, 葉群層の蒸 発散作用により日最高気温の時刻でも外気温よりわ ずか上昇するだけであった。夜間から早朝にかけて は放射冷却により外気温より低かった。土壤表面温 度は, 葉群層による日射遮蔽と, 常時湿った状態に よる盛土層表面からの蒸発及び盛土層の熱容量によ り, サツキ葉群層上表面温度の日較差の $9.5^{\circ} \mathrm{C}$ に比べ $3{ }^{\circ} \mathrm{C}$ 小さかった。また, 盛土層が厚いため土壤最

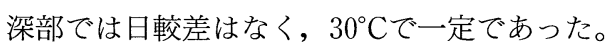

以上のように, 屋上植栽の葉群層による日射遮蔽 効果, 蒸発散作用及び盛土層表面の蒸発により, 盛 土層表面の温度の上昇がおさえられ, 盛土層表面温 度の日較差は葉群層表面よりも少なかった。

一方, 室内と天井裏の温度変化を, 室内気温・天 井裏気温・外気温の 8 月の時刻別平均値として図 5 に示す。室内気温に注目すると, 午前 6 時頃から上

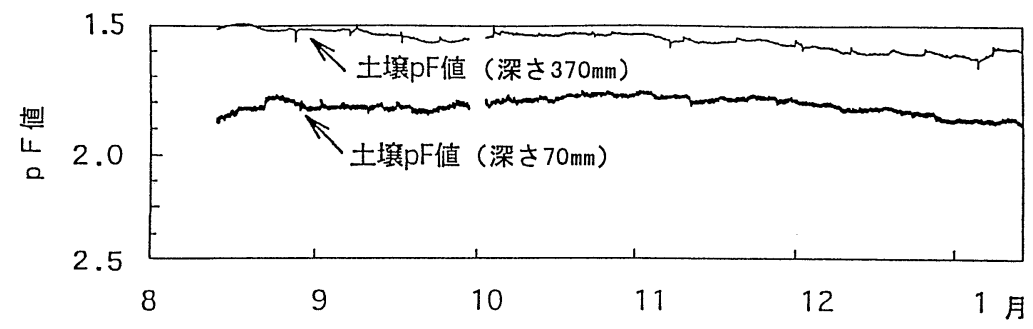

図 3 土褰 $\mathrm{pF}$ 值の長期変化

Fig. 3 Long-term changes in soil $\mathrm{pF}$ value 

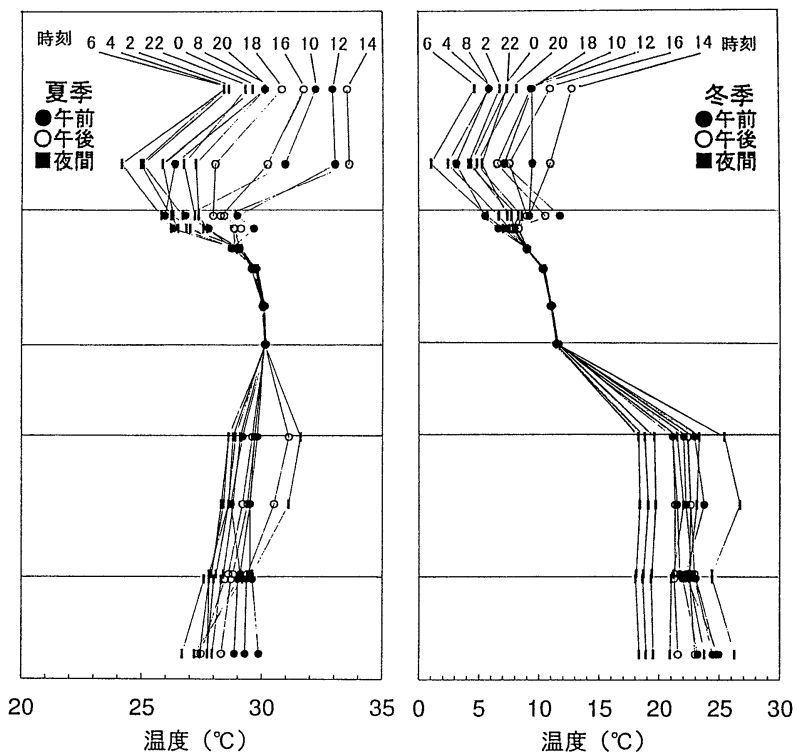

図 4 断面温度分布

Fig. 4 Cross ${ }^{-}$sectional temperature distribution

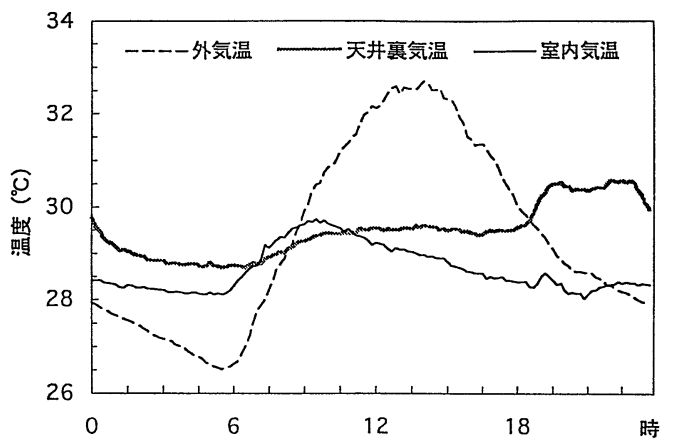

図 58 月における外気温・天井裏気温・室内気温の時 刻別月平均值

Fig. 5 Average monthly values for outdoor, space above ceiling and indoor temperatures at different times of day (August)

昇し始めた室内気温は午前 10 時頃に $30^{\circ} \mathrm{C}$ 近くになり それ以後下がり始めた。これは朝東側の空から日射 が入射し室内気温が上昇するが，午前 10 時頃には太 陽高度が高くなり日射の影響が少なくなり, 室内の 自動空調が利き始めて室内気温が下がるためであ る。天井裏気温は室内気温よりも高く, 特に夕方か ら夜間にかけては, 夕方居住者が帰宅して埋め込み 式の照明器具を点灯するため, 室内気温より $2{ }^{\circ} \mathrm{C}$ 高 かった。このように部屋の位置によって, 外気象条
件により天井以外の壁や空からの熱収支と, 居住者 の日常生活で生じる人工発生熱があるのが一般的で あり，人工発生熱も含めた熱環境を考察する必要が ある。

図 4 の夏季では, 室内気温は自動空調と冷房によ り土壌最深部よりも温度が低く温度勾配は温度の高 い方へ右上がりになる。しかし，天井裏気温と断熱 材下温度で午後と夜間に温度の高い点があり，これ が住人によって照明が点灯された時に当たる。特に 断熱材下温度では照明器具による放射熱を受けるこ とにより, 土壌層にも室内側にも温度勾配が出来て 熱流が上にも下にも流れる現象が起きている。

図 4 で冬季についてみると, サツキ葉群層上表面 温度は昼間は外気温に比べわずかに低く, 夜間では 放射冷却により外気温より低かった。土䁃表面温度 の日較差は夏季と同様, 葉群層上表面温度日較差よ りも少なかった。土壌最深部温度の日較差は殆どな かったが, 夏季と異なり外気温が室内気温よりも低 いため, 土壤最深部温度も低くなって天井裏気温と 比較すると大きな温度勾配が見られた。

室内気温は暖房により土壌最深部よりも温度が高 いが, 断熱材によって断熱材下の温度は, 室内気温 とほとんど変わらなかった。夏季と同様に天井裏気 温と断熱材下温度が夜間に高くなっている時間があ 
りこれは照明灯によるものである。しかし，断熱 材下温度は土壌最深部の温度が外気温の影響で低い ため，夏季と異なり熱流は天井裏から流入して，土 壌側に放熱する。

\section{5 夏から冬にかけての長期変化}

夏から冬にかけての土壤最深部温度と外気温, 及 び天井裏気温の, 各日最高・最低值を図 6 に, 図 7 に天井裏の断熱材下表面の熱流の日最大 ・最小值及 び日積算熱流の変化を示す。

前節で検討したように土壌最深部の温度変化は, 盛土層が厚いため日較差はほとんどないが長期的に は外気温に追随し， 8 月初旬と 12 月下旬では $20^{\circ} \mathrm{C} の$

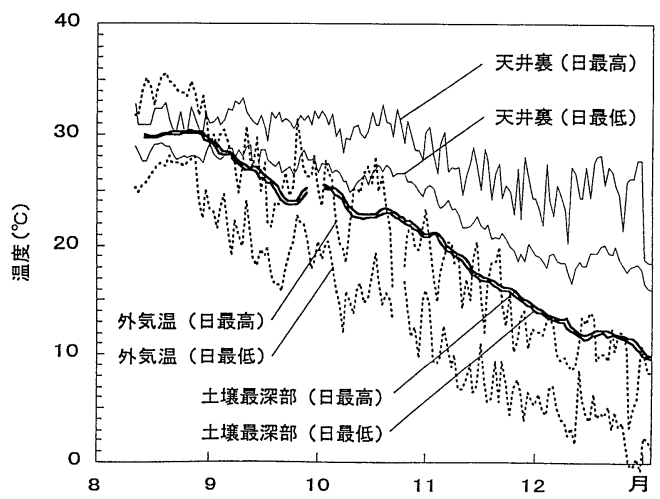

図 6 土壌最深部の日最高 - 最低温度の長期変化

Fig. 6 Long-term changes in daily maximum and minimum temperatures of deepest soil layer

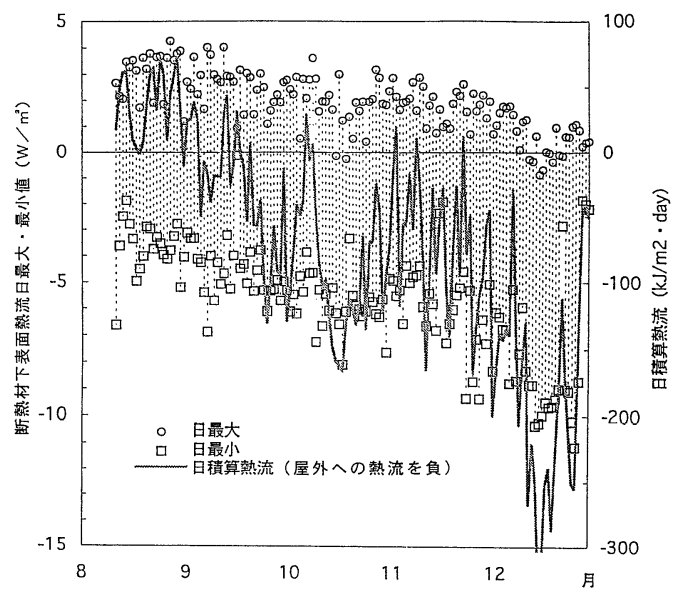

図 7 断熱材下表面熱流の日最大 - 最小值の長期変化

Fig. 7 Long-term changes in maximum and minimum heat-flow values on lower surface of insulation
差が生じていた。熱流は夏季の 8 月から 9 月中旬ま ではほとんどの日で盛土層側から室内側に流入して いるが，その日積算量は $70 \mathrm{~kJ} / \mathrm{m}^{2} ・$ day におさえら れていた。天井裏気温の日最低温度が, $25^{\circ} \mathrm{C}$ 以上の パッシブクーリングを期待したい時期は図 7 からお よそ10月下旬までであるが，その時期には熱流が室 内側から盛土層側に流出する日も多く, パッシブク ーリング効果がみられる。11月以降では, 外気温が 下がるに従って熱流は, 室内側からの流出量が増し, 12月では常に室内側からの流出になり, 暖房の点か ら室内熱環境の悪化を招くことになる。しかし, 屋 上植栽と厚い土壤層や断熱材によって室内側からの 日積算熱流はおよそ $300 \mathrm{~kJ} / \mathrm{m}^{2}$ ・day, 熱流の日最大 值は $15 \mathrm{~W} / \mathrm{m}^{2}$ に押さえられている。

\section{3. サツキ屋上植栽の数值計算のためのモデル化 とパラメータ等の設定}

第 2 章で, 特定条件下での屋上植栽の熱環境調整 効果を実測により明らかにしたが, 本章と次章では, 更に屋上構造と室内気温及び外気象条件を入力条件 として数值計算を実行し, 屋上植栽の熱環境調整効 果を考察する。

屋上植栽が室内の熱環境にどのような効果を与え ているかは, 室内気温の変化を考察することにより その効果を把握することができる。しかし, 室内気 温に作用する要素は多く, 屋根からの熱流量だけで なく壁面や空, 床を通して熱貫流やすきま風などで あり,また, 住まい方による空調作動時間, 空調設 定温度, 室内発熱量等がある。これらの要素全てを 考慮して実測しても, 結果としては複合されたもの であり，屋上植栽による室内熱環境の調整効果を考 察することが結果としては困難となる。

そこで, 外気象条件に加えて室内気温も入力条件 とし, 室内気温に接している天井表面温度を数值計 算によって求め, 室内気温との差によって屋上植栽 の室内熱環境調整効果を考察することとする。本章 では, 屋外からサツキ葉群層, 盛土層, 室内までの 伝熱をモデル化し，数值計算に必要なパラメータを 設定する。

\section{1 伝熱モデル化}

外気象条件と室内気温を入力条件として天井表面 温度を数值計算から求めるには, 屋外からサツキ葉 群層, そして盛土層, 室内天井表面から室内まで, 図 8 に示すような伝熱モデルを設定して, 同図の黒 


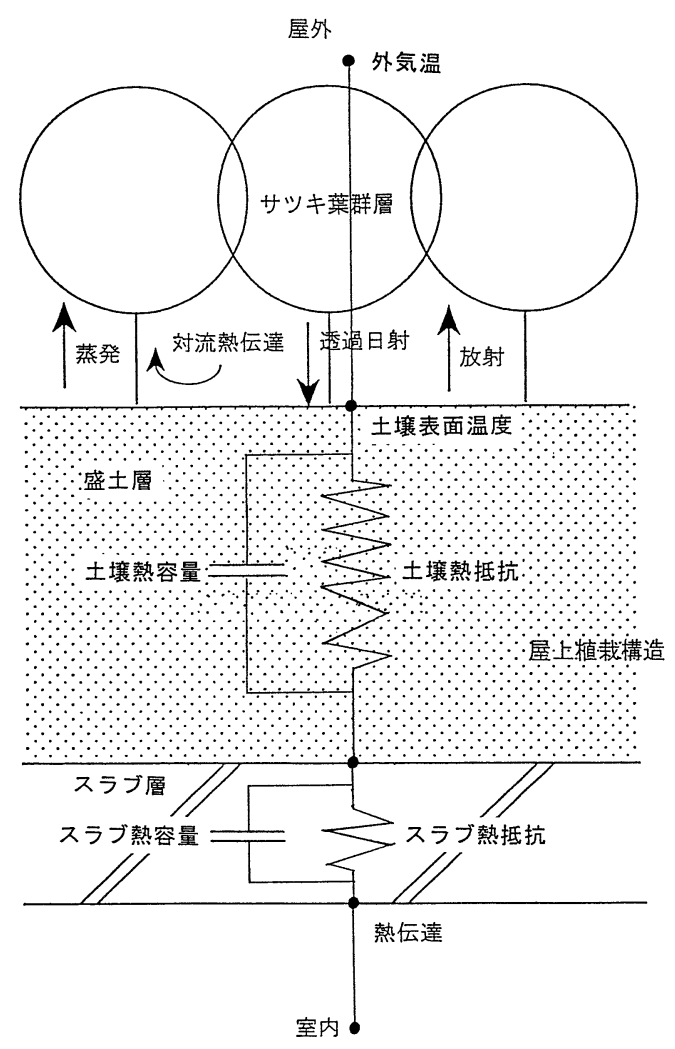

図 8 サツキ植栽伝熱モデル概念図

Fig. 8 Outline of azalea heat transmission model

点の位置に質点を設定した。

サツキ葉群層が直接的に影響する盛土層表面での 熱収支式は盛土層内への等価的熱伝導率, 葉群層の 日射透過率，葉群層下表面温度，葉群層下表面と盛 土層表面との間の気温と風速によって次式で表せ る。

$\mathrm{Gg}=\mathrm{tj}+\alpha \mathrm{c}(\theta \mathrm{a}-\theta \mathrm{g})+\sigma\left(\mathrm{Ts}^{4}-\mathrm{Tg}^{4}\right)+\mathrm{W}$

$\mathrm{Gg}$ : 盛土層内への等価的熱伝導量 $\left[\mathrm{W} / \mathrm{m}^{2}\right)$

$\mathrm{t}$ : サツキ葉群層の日射透過率

$\mathrm{j}$ : 法線面直達日射及び天空日射 $\left[W / \mathrm{m}^{2} 〕\right.$

$\alpha \mathrm{c}$ : 対流熱伝達率 $\left[\mathrm{W} / \mathrm{m}^{2} \mathrm{~K}\right.$ )

$\theta \mathrm{a}$ ：盛土層とサツキ葉群層間気温 $\left[{ }^{\circ} \mathrm{C}\right]$

Ts：サツキ葉群層下表面温度〔 $\mathrm{K} 〕$

$\theta \mathrm{g}, \mathrm{Tg}$ ：盛土層表面温度 $\left[{ }^{\circ} \mathrm{C}, \mathrm{K}\right]$

$\sigma$ : シュテファン・ボルツマン常数 $\left[\mathrm{W} / \mathrm{m}^{2} \mathrm{~K}^{4}\right]$

$\mathrm{W}$ : 盛土層表面の蒸発量 $\left[\mathrm{W} / \mathrm{m}^{2} 〕\right.$

※ Gg については, 熱伝導の他に盛土層内の水分

移動, 水蒸気移動に伴う伝熱が存在するが, ここ ではこれらをすべて含めて，等価的熱伝導として

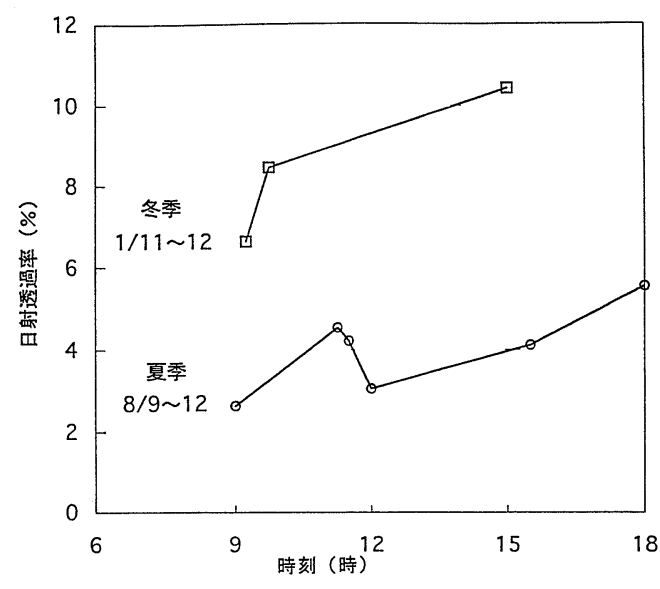

図 9 サツキ葉群層の日射透過率

Fig. 9 Ratio of sunlight passing through azalea leaf -cluster layer

扱う。

※長波長放射収支については，土壌表面と葉群層 表面はともに黒体と仮定した。

計算の入力条件は外気象条件として外気温, 温度, 水平面全天日射量, 風速, および室内気温であるこ とから，数值計算のため事前に検討しておかなけれ ばならないパラメータは(1)サツキ葉群層からの日射 透過率，(2)盛土層表面日射反射，(3)サツキ葉群層と 盛土層表面の放射授受の計算に必要なサツキ葉群層 下面温度, (4)盛土層表面の対流熱伝達量を求めるた めのサツキ葉群層と盛土層の間の気温及び風速（以 下サツキ葉群層下風速とする),(5盛土層表面の蒸発 量, である。さらに, 盛土層の熱物性値として, 土 壌の等価的熱伝導率と容積比熱がある。

以下では第 4 章の数值計算で必要となる上記のパ ラメータについて検討する。

\section{2 サツキ葉群層の日射透過率}

サツキが植栽されている平面を25分割し，各測定 点で午前, 正午前後, 午後の各時刻に扔ける, 水平 面全天日射量・サツキ葉群層透過日射量・土㙵表面 反射日射量を測定した。測定期間は夏季の 1995 年 8 月 8〜10日, 冬季の1996年 1月11〜 12日である。図 9 に日射透過率の算出結果を示す。日射透過率は夏 季よりも冬季のほうが高かった。日射透過率を季節 毎にほぼ一定と見なして, 数值計算上では夏季 $4 \%$ ， 冬季 $9 \%$ とした。

盛土層表面反射日射量は，サツキ葉群層上表面の 入射日射量の $1 \%$ 以下であったため, 数值計算上で 

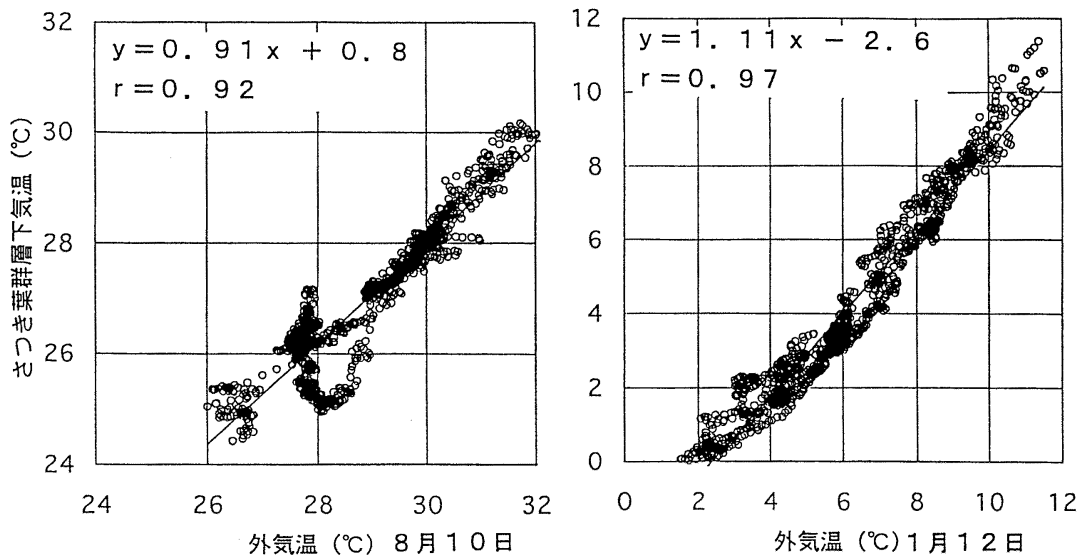

図10 サツキ葉群層下気温と外気温の関係

Fig. 10 Relationship between temperature below azalea leaf-cluster layer and outdoor temperature

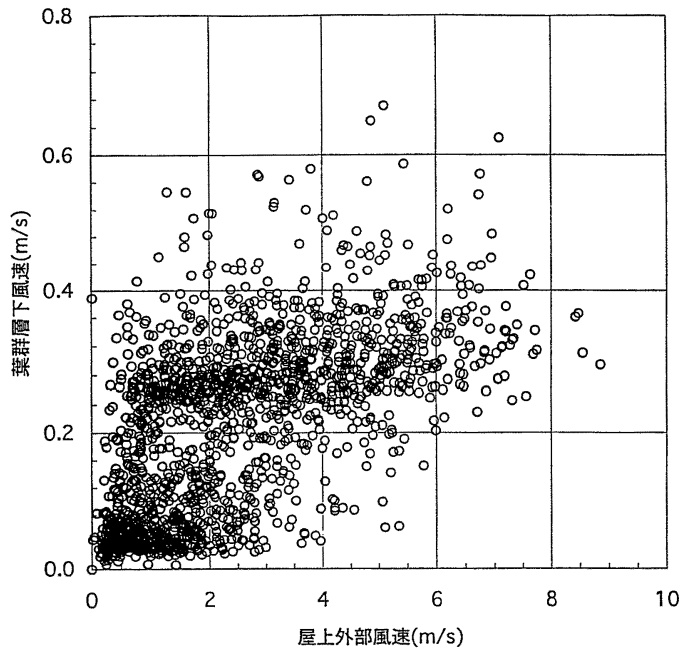

図11-1＼cjkstart屋上外部風速とサツキ葉群層下風速の関係 (1995年 8 月 8 日〜 9 日・測定間隔 1 分)

Fig. 11-1 Relationship between exterior wind velocity and wind velocity below azalea leafcluster layer (1995/8/8-8/9)

はサツキ葉群層透過日射量はすべて盛土層表面で吸 収するものとして扱った。

\section{3 サツキ葉群層下表面温度}

盛土層表面長波長放射授受は，サツキ葉群層によ って上方を覆われているために，サツキ葉群層下表 面との間で行われるとして扱った。前章の実測結果 から葉群層上表面温度は外気温と比較して，日中は 高く夜間は低いが，数度の範囲であることからサツ キ葉群層下表面温度については，日射や大気放射の

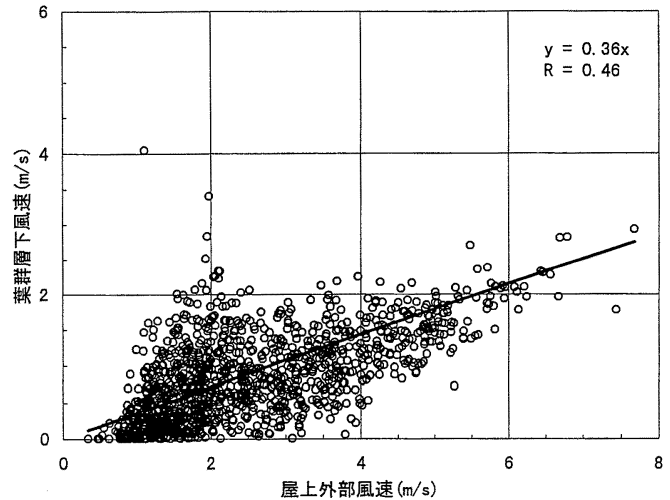

図11-2 屋上外部風速とサツキ葉群層下風速の関係 (1995年 1 月 10 日 13日・測定間隔 1 分)

Fig. 11-2 Relationship between exterior wind velocity and wind velocity below azalea leaf-cluster layer (1996/1/10-1/13)

影響が少ないこと，などの理由から次節で求めるサ ツキ葉群層と盛土層の間の気温と等しいとした。

3.4 サツキ葉群層と盛土層の間の気温

典型的な晴天日における夏季と冬季のサツキ葉群 層と盛土層との間の気温と，外気温の関係を図10に 示す。サツキ葉群層と盛土層との間の気温は, 夏季・ 冬季共にサツキ葉群層上の気温に比べ $2^{\circ} \mathrm{C}$ 程度低く 直線関係にあった。

\section{5 盛土層表面の対流熱伝達率}

盛土層表面での対流熱伝達率に必要なサツキ葉群 層下の風速を求めるにあたり，夏季の1995年 8 月 8 〜 9 日，冬季の1996年 1 月10〜13日の期間測定した 
サツキ葉群層下と屋上上空の風速を図11-1, 図11-2 に示す。

夏季ではサツキ葉群層下風速は, 周囲の中低木・ サツキ葉群層による遮蔽の影響によりおよそ 0.4 $\mathrm{m} / \mathrm{s}$ 以下であったので, サツキ葉群層下風速は常に $0.4 \mathrm{~m} / \mathrm{s}$ とした。冬季は夏季と違い, 周囲の多くの樹 木が枯れて，遮蔽物が少なくなったことからサツキ 葉群層下風速は外部風速と相関がみられた。そこで, 外部風速との回帰分析を行い, サツキ葉群層下風速 は図11-2に示した回帰式を用いて求めた。

さらに, 盛土層表面の対流熱伝達率はユルゲスの 式泉を用いて求めた。

\section{6 盛土層表面の蒸発量}

盛土層表面には，保水材が埋められており，定期 散水が行われていたため常に湿った状態であった。 そこで, 数值計算においても盛土層表面は湿った状 態として扱い, 盛土層表面蒸発量は自由水面と仮定 したときの蒸発量に,濡れ係数を 0.7 とて乗じた值 とした ${ }^{10)}$ 。

\section{7 土壤の熱物性值の推定と検証}

土壤の熱物性值は, その含水率によって変化する が，実測により得られた土壌含水率は湿潤状態で一 定であった。そこで次章の数值計算では，土壌含水 率は一定の湿った状態に保たれているとする。

この湿潤状態における土壌熱物性值を第 2 章の実 測結果を用いて以下の方法で推定する。計算は差分 法(クランクニコルソン法 $\left.{ }^{11}\right)$ をを用いて，土壌表面と 天井表面の熱流の実測值を境界条件として, 屋上植 栽の断面温度日変化を求めることとし，その時の土

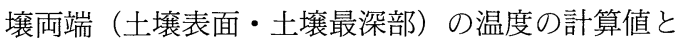
実測値の誤差が最小になるように，熱物性值を変化

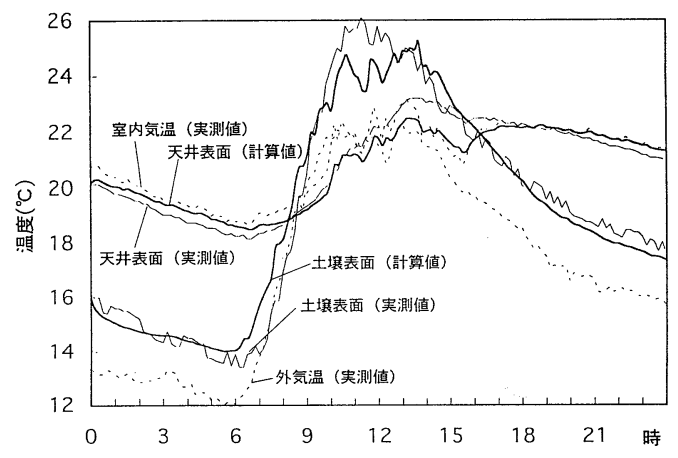

図12 数值計算モデルの検証

Fig. 12 Verification of numerical simulation model
させて収束計算をおこない, 土壌熱物性值を推定し た。推定計算で用いた実測値は，降水後 1 日以上た った典型的な晴天日で，気象条件，室内気温が穏や かに変化する日を用いた。得られた等価的熱伝導率 と容積比熱は，それぞれ，0.28～0.31 W/mK， $1500 \sim 1800 \mathrm{~kJ} / \mathrm{m}^{3} \mathrm{~K}$ の範囲であった。

さらに, 推定した上記の值と, 前述の伝熱モデル の設定について，その妥当性を検証した。検証には 推定日の気象条件を境界条件として, 前述のモデル に入力し, 断面温度の 1 日の日変化を計算した。こ の計算值と実測値の比較の 1 例を図 12 に示す。実測

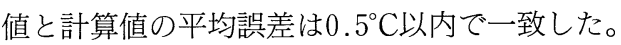

\section{4. 数值計算による室内熱環境調整効果の検討}

前章では数值計算に必要なサツキ屋上植栽のモデ ル化を行い, それらの熱物性值を求めた。本章では 入力条件として外気象条件及び室内気温を設定し て，いろいろな屋上の断面構造の場合について数值 計算を行い, 屋上植栽の室内熱環境調整効果を考察 する。

\section{1 屋上構造条件の設定}

屋上構造条件として，室内の熱環境調整効果に影 響を及ぼす項目としては植栽の有無の他に，断熱材 の有無, 盛土層の厚さや土壌の含水状態等が考えら れることから，図13に示す 5 パターンの断面構造に ついて考察した。

No.1は本研究で実測の対象とした屋上構造のう ち，排水層を除いたもので盛土層の下はコンクリー 卜層であり，コンクリート層下の断熱材下は天井裏 空間がなく直接天井表面である。盛土層の厚さは600 $\mathrm{mm}$ ，コンクリート層は2 $40 \mathrm{~mm}$ で断熱材は50 mm とした。No.2はNo.1の断面構造から断熱材を除い たものである。No.3については, 盛土の層を $80 \mathrm{~mm}$ と薄くし，更に断熱材を除いたものである。No.4は No. 2 と同じ構造で土壤の含水率が乾燥状態である とした場合である。No.5は，植栽をしていない RC 造建築屋根構造で押さえコンクリートに軽量コンク リート $60 \mathrm{~mm}$ を使用し，コンクリート層は $160 \mathrm{~mm}$, 断熱材 $50 \mathrm{~mm}$ を使用した構造である。

コンクリート，軽量コンクリート，断熱材等の容

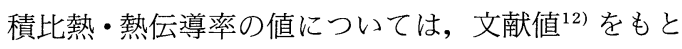
に表 1 のように設定した。押さえコンクリートの表 面は日射吸収率を 0.8 ，放射率は 0.9 とした。

室内側の熱伝達率は $9.8 \mathrm{~W} / \mathrm{m}^{2} \mathrm{~K}$ で一定とした。 

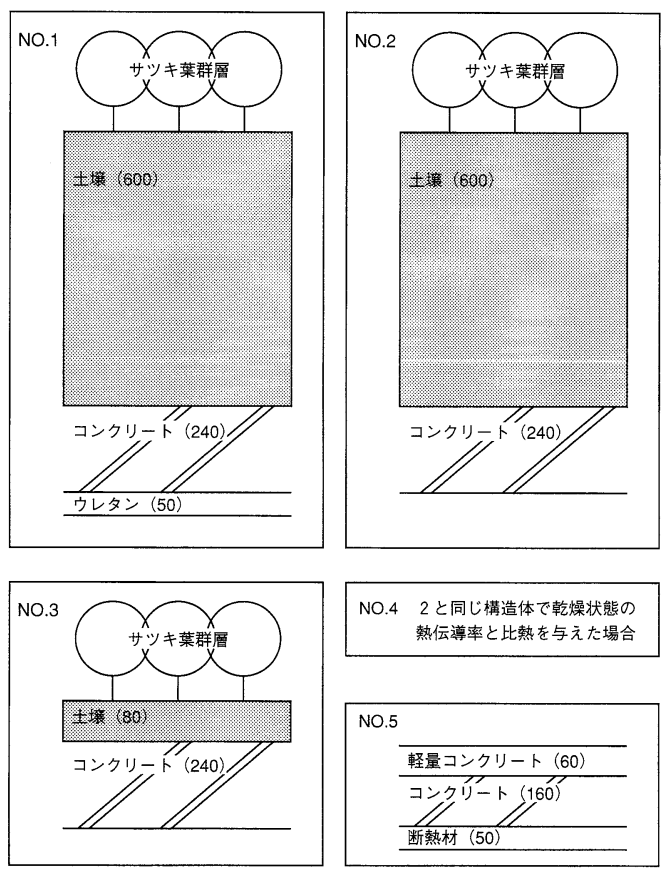

（）内は厚さ (単位 $: \mathrm{mm})$

図13 数值計算のための屋上構造パターン

Fig. 13 Roof-top planting structural pattern for numerical simulation

表 1 一般材料の熱物性值

Table 1 General material thermal property

\begin{tabular}{lcc}
\hline \multicolumn{1}{c}{ 材料 } & $\begin{array}{r}\text { 熱伝導率 } \\
(\mathrm{W} / \mathrm{mK})\end{array}$ & $\begin{array}{c}\text { 容積比熱 } \\
\left(\mathrm{kJ} / \mathrm{m}^{3} \mathrm{~K}\right)\end{array}$ \\
\hline コンクリート & 1.6 & 2010 \\
ウレタン & 0.025 & 30 \\
軽量コンクリート & 0.524 & 1871 \\
\hline
\end{tabular}

表 2 土壌熱物性值

Table 2 Soil thermal property

\begin{tabular}{lcc}
\hline & $\begin{array}{c}\text { 等価的熱伝導率 } \\
(\mathrm{W} / \mathrm{mK})\end{array}$ & $\begin{array}{c}\text { 容積比熱 } \\
\left(\mathrm{kJ} / \mathrm{m}^{3} \mathrm{~K}\right)\end{array}$ \\
\hline 湿潤時 & 0.3 & 1600 \\
乾燥時 & 0.1 & 1000 \\
\hline
\end{tabular}

また，土畩含水率は前章で検討した湿潤状態とす るが，土の乾湿の状態による違いを検討するために 乾燥状態の場合を加える。なおここで乾燥状態の土 壤の熱物性值は既往の文献 ${ }^{13)}$ から求め, 湿潤状態の 熱物性値とあわせて表 2 に示す。湿潤状態と乾燥状 態の重量含水率は各々 $260 \%$ と $100 \%$ であるが, 数字
が大きいのは対象とした土壌が人工土壤でありパー ライト（比重：0.6 Kg/l） を主体としているためで ある。

4.2 解析対象とした期間と入力条件

室内熱環境調整効果は第 2 章で明らかにしたよう に季節によっても異なる。そこで, 本章では夏季 $(8$ 月）冬季（12月）の各々 1 ケ月間を解析の対象期間 とした。入力条件の 1 つである外気象条件は, 気温, 絶対湿度, 法線面直達日射量, 天空日射量, 夜間放 射量, 風速として, 空気調和・衛生工学会空調負荷 計算用標準気象データ（大阪）から得た。

もう 1 つの入力条件である室内気温については, 夏季は冷房を使用するとして $26^{\circ} \mathrm{C}$ 一定, 冬季は暖房 を使用するとして $18^{\circ} \mathrm{C}$ 一定として設定した。なお， 一般の住宅では夏季に扔いては, 冷房を常時使用し ないことが多いため, 午後から夜にかけて冷房した 場合も加え, その日変化については, 第 2 章の実測 結果で得られた 8 月の典型的な晴天日の外気象条件 と室内気温条件を与えた。

\section{3 数值計算方法の概要}

計算は差分法(クランクーニコルソン法)を用いた。 各層の温度の初期条件は, 入力外気温の 1 日目の平 均気温として設定した。刻み時間は 10 分とし, 測点 間の刻み幅は各材料ごとに刻み時間から, Courant 条件を基準に出来るだけ精度が高くなるように設定 した。長期変化の計算の際は, 1 週間程度の助走期 間を設けて断面温度の履歴を十分計算した上で 1 ケ 月間の屋上植栽断面温度変化を求めた。日変化の計 算の際は, 1 日周期の境界条件の連続計算を, 計算 断面温度が収束するまで行った。

\section{4 計算結果及び考察}

4.4 .1 室内気温一定の場合

夏季と冬季 1 ケ月間の各屋根構造における天井表 面温度の比較を図14と図15に示す。

植栽されているNo. 3 と植栽のないNo.5を比較 してみると, 夏季については, 天井表面温度の日較 差は $0.5^{\circ} \mathrm{C} て ゙ あ り$, 外気温の日較差抢よそ $9^{\circ} \mathrm{C}$ に比べ て殆どないと云える。1 月月を通してNo.3の方が No. 5 よりも天井表面温度は, ほぼ $0.5^{\circ} \mathrm{C}$ 低く屋上植 栽の効果が表れている。さらに, No.3は夜間に室内 気温より低くなる日があり，パッシブクーリング効 果があるといえる。冬季では, No. 3と No.5の天井 表面温度の日較差は $0.5 \sim 1{ }^{\circ} \mathrm{C}$ で外気温の日較差 $10^{\circ} \mathrm{C}$ に比べ殆どないといえるが，No. 3の方がNo. 5 


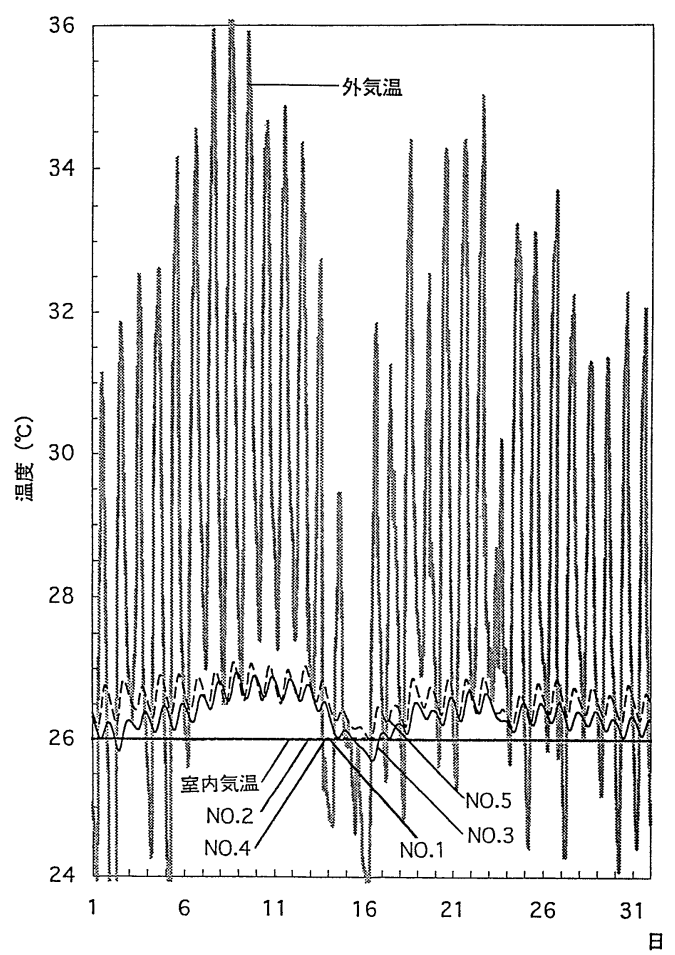

図14 8 月室内気温一定 $\left(26^{\circ} \mathrm{C}\right)$ のときの屋上植栽構造 の違いによる天井表面温度の比較

Fig. 14 Comparison of changes in ceiling surface temperature resulting from differences in roof-top planting structure under constant $\left(26^{\circ} \mathrm{C}\right)$ indoor temperature conditions during August

よりも天井表面温度は室内気温に比べて $1^{\circ} \mathrm{C}$ 低い。 これは夏季よりも冬季の方が外気温と室内気温の差 が大きく, No. 5の断熱材の効果があらわれている。

次に, 同じ $600 \mathrm{~mm}$ の厚い盛土層を持つ No. 1 ,

No. 2, No.4では, 夏季, 冬季ともに天井表面温度は ほとんど変わらず,室内気温との差は $0.1^{\circ} \mathrm{C}$ 以内でほ ぼ等しい。このことは, 土壤含水率の違いは殆ど影 響せず，断熱材の有無による効果等もほとんどみら れず，厚い盛土層とサツキ葉群層の日射遮蔽効果及 び蒸発散作用による効果が大きいといえる。

\subsection{2 室内気温が変化する場合}

図16に夏季の晴天日に扔ける外気温, 室内気温及 び天井表面温度の時間変化を示す。まずはじめに, 設定した室内気温の日変化の特徵を述べておく。午 前中は冷房していないため午前 6 時過ぎから室内気 温が上昇している。10時頃までは空から日射が侵入

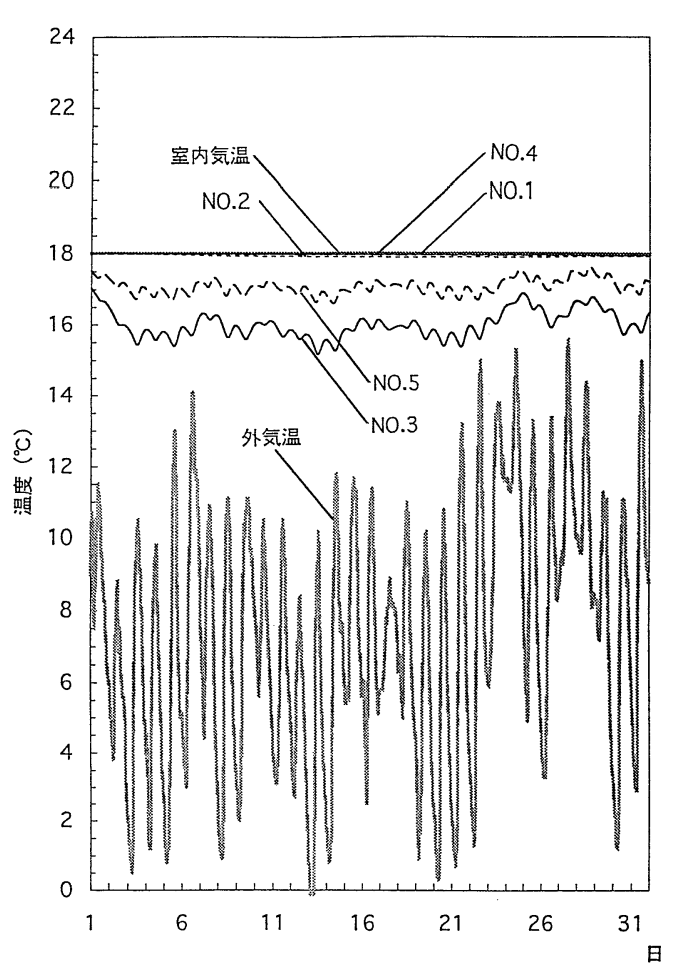

図15 12月室内気温一定 $\left(18^{\circ} \mathrm{C}\right)$ のときの屋上植栽構造 の違いによる天井表面温度の比較

Fig. 15 Comparison of changes in ceiling surface temperature resulting from differences in roof-top planting structure under constant $\left(18^{\circ} \mathrm{C}\right)$ indoor temperature conditions during December

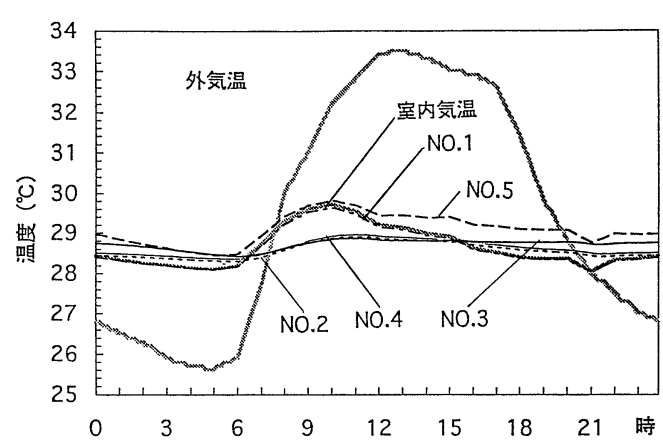

図16 8月自然室温のときの屋上植栽構造の違いによる 天井表面温度の日変化

Fig. 16 Daily changes in ceiling surface temperature resulting from differences in roof-top planting structure under natural indoor temperature conditions durring August 
するため，自動空調が作動しているにもかかわらず 室内気温は $30^{\circ} \mathrm{C}$ 近くまで上昇する。10時以降は日射 があたらず室内気温は下がりはじめ，21時頃が最低 で28ㄷとなる。

つぎに, 計算結果を述べる。植栽のあるNo.3の天 井表面温度は, 盛土厚が $80 \mathrm{~mm}$ と薄いにもかかわら ず, 外気温の高い 6 時から 15 時の間では, $600 \mathrm{~mm}$ の 厚い盛土層をもつNo.2, No.4の天井表面温度と比 べ殆ど同じであり，室内気温よりも低く推移してい る。これは，外気温が高くなっても植栽による日射 遮蔽効果と葉群層の蒸発散作用及び盛土層表面から の蒸発により盛土層の温度上昇が抑えられ, 室内気 温が上昇した時に, 熱を屋上植栽層に逃がすパッシ ブクーリング効果により, 天井表面温度は低く抑え られているためである。

植栽のないNo. 5の天井表面温度は, 昼間外気温 の上昇とともに温度が上がり始め 10 時頃の室内気温 の最高時の温度よりも上昇し最高 $30^{\circ} \mathrm{C}$ に達する。さ らに, 室内気温が下がってもコンクリートの熱容量 により天井表面温度はほとんど下がらない。

屋上植栽があり断熱材を持つNo.1では，屋上植 栽による盛土層の温度上昇が抑えられているにも関 わらず，日中室内気温が上昇した時に断熱材によっ て室内気温の上昇を盛土層側に放熱できないため に, 6 時から15時の間では, 同じ屋上植栽のある No. 2, No. 3, No.4 4 比較して, 室内気温に追随して天 井表面温度が高くなっている。

これに比べNo. 2, No.4では断熱材がないため, No. 3 と同様昼間室内気温が上昇した時にその熱量 を盛土層側に放熱することにより，天井表面温度は 上昇しない。

\section{5. まとめ}

本研究では, 先ず, サツキ屋上植栽が施され, 盛 土層が厚く，断熱材のある $\mathrm{RC}$ 造建築を対象に実測 を行い以下の点を明らかにした。

1. 夏季において葉群層上表面温度は, 葉群層の日 射遮蔽と蒸発散作用により日中外気温と比較して 数度しか高くない。

2 . 盛土層表面温度の日較差は, 葉群層の日射遮蔽 と盛土層が常に湿潤状態にある為の蒸発によって 葉群層表面温度の日較差に比べて小さい。

3 ．屋上植栽の日射遮蔽と蒸発散作用及び盛土層表 面の蒸発作用と厚い盛土層により土壌最深部温度
の日変化は見られず，ほぼ一定であった。

4.8月では熱流はほとんぞ盛土層側から室内側へ と流入するがその日積算量は $70 \mathrm{~kJ} / \mathrm{m}^{2}$ day に抑 えられていた。9月以降天井裏気温の最低值が $25^{\circ} \mathrm{C}$ 以上の温度でパッシブクーリング効果を期待 したい時期では熱流は室内側から盛土層側に放熱 する日が多くパッシブクーリング効果が行われて いた。

5.11月以降は外気温が低くなり熱流は室内側から の流出がほとんどとなるが, 屋上植栽と断熱材に より日積算熱流は $300 \mathrm{~kJ} / \mathrm{m}^{2}$ day に抑えられてい る。

次に, 数值計算によって屋上植栽の室内熱環境調 整効果を考察するが, 数值計算に先だち, サツキ葉 群層が盛土層表面における熱収支に及活す影響を表 現できる伝熱モデルを設定し，そのモデルに沿った 数值計算に必要なパラメータについてその值を求め た。

さらに, 数値計算の対象とする屋上構造条件は, 実測結果をもとに屋上植栽の有無, 断熱材の有無, 盛土層の厚さ，盛土層の含水率の違いを考慮して設 定した。

入力条件として室内気温を夏季冷房温度 $26^{\circ} \mathrm{C}$, 冬 季暖房温度 $18^{\circ} \mathrm{C}$ 一定として，8月と 12 月の各々 1 ケ 月の期間を対象として外気象を与えて数值計算を行 つた。また，8月の典型的な晴天日を取り上げ冷房 を午後から夜にかけて使用した場合の 1 日の温度変 化のある室内気温を設定して数值計算を行った。以 下に数値計算の結果を述べる。

(1)室温を一定とした場合には, 盛土層が $80 \mathrm{~mm}$ と 薄い場合と植栽がなく断熱材のある場合は，両方と も外気温と日射量に対応した日変化が生じる。しか し，植栽のある場合は夏季においてパッシブクーリ ング効果が生じる日がある。冬季は断熱材のあるほ うが天井表面温度の低下が少なかった。厚い盛土層 の屋上植栽構造は, 植栽による蒸発散作用と日射遮 蔽及び盛土層表面からの蒸発作用と， $600 \mathrm{~mm}$ の厚 い盛土層の熱容量により, 夏季・冬季共に外気温の 影響を殆ど受けない。

(2)室温を変化させた場合は，植栽のある薄い盛土 層も厚い盛土層でも，植栽の効果及び盛土層表面か らの蒸発作用の影響で, 室内気温が上昇してもパッ シブクーリング効果により天井表面温度は上昇しな い。植栽のない場合は日中吸収された日射熱等がコ 
ンクリートの熱容量により蓄えられ夜間も温度が高 い。また，植栽のある場合でも断熱材があると室内 気温の上昇時にコンクリート及び盛土層への放熱が 出来ず，室温と同様な温度上昇を示した。

\section{附記}

※ クランク-ニコルソン法

熱伝導方程式の解法の 1 つである差分法において, 熱フラックスは平均温度から求められる。平均温度 は各要素の節点における温度から求めるが，その時

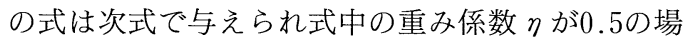
合は, 新旧の温度の平均が熱フラックスの計算に用 いられ (時間) 中心差分法またはクランクーニコルソ ン法と呼ばれる。

$$
\begin{aligned}
& \bar{T}=\eta T^{j+1}+(1-\eta) T^{j} \\
& \text { ※ルゲスの式 }
\end{aligned}
$$

ユルゲスが提案した対流熱伝達率の実験式。対象と なる面の表面状態により粗面と普通面に分け, 普通 面の場合は風速によって以下のように回帰式を与え ている。

$$
\begin{gathered}
\alpha \mathrm{c}=5.0+3.4 \mathrm{v}(\mathrm{v} \leqq 5 \mathrm{~m} / \mathrm{s}) \\
\alpha \mathrm{c}=6.14 \mathrm{v}^{0.78}(\mathrm{v}>5 \mathrm{~m} / \mathrm{s}) \\
\alpha \mathrm{c} \text { : 対流熱伝達率 } \\
\mathrm{v}: \text { 風速 }
\end{gathered}
$$

\section{謝辞}

本研究は, 大阪ガス侏との共同研究であり, 大阪 ガス(株の勝瀬 進氏, 志波 徹氏両氏には, 多大な ご協力を頂いたことをここに記して, 感謝の意を表 します。

\section{引用文献 \\ 1）梅干野, 他：屋上植栽による照り返し防止・焼け込}

み防止効果, 日本建築学会建築工学論文集, pp. 133 $-140,1983$

2）洞田，他：屋上緑化面の熱特性に関する研究，日本 建築学会大会学術講演梗概集 (北海道), pp. 73-74, 1995

3）三小田, 他：屋上芝生植栽の導入効果に関する実験 的研究その 1 , その 2 , 日本建築学会大会学術講演 梗概集 (関東), pp. 1525-1526，1993，(東海)，pp. 439-440, 1994

4）石原, 他：パッシブ手法による夏季の省エネルギー 効果に関する研究, 第 2 報, 空気調和・衛生工学会 論文集，No. 57, pp. 63-71，1995

5）野島,他：屋上緑化による夏期の建築物および熱負 荷の軽減効果の実証的研究, 日本緑化工学会誌, 第 20 巻, 第 3 号, pp. 168-176, 1995

6) Harazono, Y, et al: Effects of rooftop vegetation using artificial substrates on the urban climate and the thermal load of buildings, Energy and Buildings, 15(3-4), pp. 435-442, 1991

7）梅干野, 他：芝生葉群層の熱収支特性に関する実験 研究, 日本建築学会計画系論文集, 第 452 号, pp. 31 -39, 1994

8）堀口，他：芝生植栽の水収支特性に関する実験研 究, 日本建築学会計画系論文集, 第483号, pp. 7380, 1996

9）渡辺 要：建築計画原論 II, 丸善, pp. 63-64, 1997

10）尾島, 他：地域環境アセスメントにおける地表面熱 収支理論の応用研究第 2 報 地表面熱収支の計算 法と実測, 日本建築学会論文報告集, 第265号, pp. 93-103, 1978

11）ゲイロン S. キャンベル：パソコンで学ぶ土の物理 学, 鹿島出版会, pp. 28, 1993

12）松尾, 他：空調設備の動的熱負荷計算入門, 建築設 備技術者協会，pp. 55，1993

13）日本機械学会編：伝熱工学資料 第 4 版, 丸善(侏), 1986

(1997. 5. 8受理)

\section{Summary}

Rooftop planting has thermal control effects on indoor environment. The effects, however, very greatly according to the building structure, residents' daily activities, and local meteorological conditions as well as with the planting structure. The present paper uses two approaches to discuss the thermal control effects of rooftop planting on the indoor environment of reinforced-concrete (RC) building.

First, we selected occupied RC building for a survey. From summer to winter, we measured the cross -sectional temperature and heat flow distribution from the roof to the occupied room. By reviewing the 
results of this survey, we clarified the thermal control effects of rooftop planting under conditions disctated by residents' daily activities, planting structure, and building structure.

Then we simulated numerically different room temperature conditions and sectional structures of roofs, including the soil layer thickness, water content, heat insulating material, and rooftop planting. Through this simulation, we calculated the long-term and daily changes of the room-side surface temperature of the ceiling. Using the simulation data as indices, we discuss the control effects of rooftop planting on the indor thermal environment. 